\title{
EFFECTS OF BODY POSITION ON SLEEP RELATED DISORDERED BREATHING IN A PATIENT WITH STEINERT'S DISEASE
}

\author{
MARCIA PRADELLA, MARIA SUNSERI, GERARD FERRIERE
}

\begin{abstract}
SUMMARY - Sudden changes in respiratory patterns observed during polysomnographic studies may suggest a positional form of SAHS (sleep apnea-hypopnea syndrome). We report the case of a 37-year-old patient with Steinert's disease with this form of SAHS. Breathing during sleep could be regularized by a simple positional control.
\end{abstract}

KEY WORDS: sleep apnea-hypopnea syndrome (SAHS), Steinert's disease, positional sleep apnea-hypopnea syndrome.

Efeito da posiç̣̂o corporal sobre distúrbio respiratório relacionado ao sono em um paciente com doenga de Steinert.

RESUMO - A observação de mudanças abruptas do padrão respiratório durante estudo poligráfico do sono pode sugerir que estamos diante de síndrome de apnéia-hipopnéia ligada ao sono (SAHS) associada à postura adotada durante o sono pelo paciente. Relatamos o caso de um paciente de 37 anos com doença de Steinert e esta forma de SAHS. A respiração durante o sono pode ser regularizada por simples controle postural.

PALAVRAs-CHAVE: sindrome de apnéia-hipopnéía do sono (SAHS), doença de steinert, sindrome de apnéla-hipopnéla posicional do sono.

Over the past few years a small number of studies have shown that in patients with sleep apnea-hypopnea syndrome (SAHS) change from the supine to the lateral position is associated with a significant decrease in apnea and hypopnea, particularly in NREM sleep. These studies suggest that the subjects likely to benefit by sleeping on their side are those with only a minor degree of obesity. On the basis of these observations, sleep position training has been proposed to reduce time spent in the supine position 1-7.

\section{CASE REPORT}

We report here the case of a patient (DL, 37 years old) with myotonic dystrophy (Steinert's disease), addressed because of repetitive respiratory infections and snoring. The patient had been institutionalized since early childhood for mental deficiency. At the time of the examination, the patient was free of infection; his respiratory function analysed by spirometry showed a moderate restrictive syndrome (VC=45.5\% PV); the blood gas analyses revealed a hypoxemia $\left(\mathrm{PO}_{2}=57 \mathrm{mmHg}\right)$, normocapny $\left(\mathrm{PCO}_{2}=35 \mathrm{mmHg}\right)$ and a $\mathrm{SaO}_{2}$ of $81 \%$; his body mass index was $25.53 \mathrm{~kg} / \mathrm{m}^{2}$.

A polysomnographic (PSG) study disclosed prolonged periods of repeated obstructive apneas and hypopneas, leading to severe desaturation, sleep fragmentation and cardiac arrhythmia both in REM and NREM sleep. These periods contrasted with episodes of regular respiration with or without snoring, with continuous sleep and normal $\mathrm{SaO}_{2}$ (Fig. 1). These abrupt changes in

Sleep Laboratory, St. Luc training Hospital, Université Catholique de Louvain (Av. Hippocrate 10, 1200 Brussels, Belgium). Aceite: 9-junho-1998.

Dra. Márcia Pradella - Rua Isidoro Garcez 12 - 88063-000 Florianópolis SC - Brasil. 
Sleep Stage (MA/hS: 36)

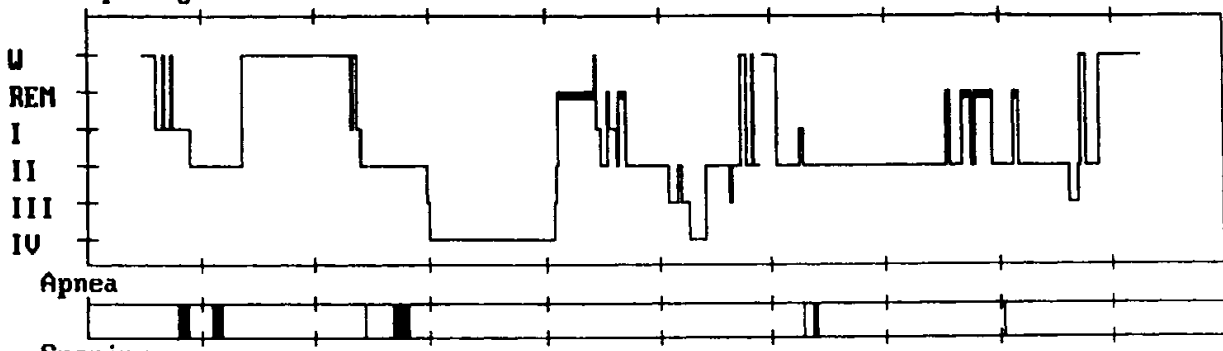

Snoring

$\mathrm{Sa} 02 \%$

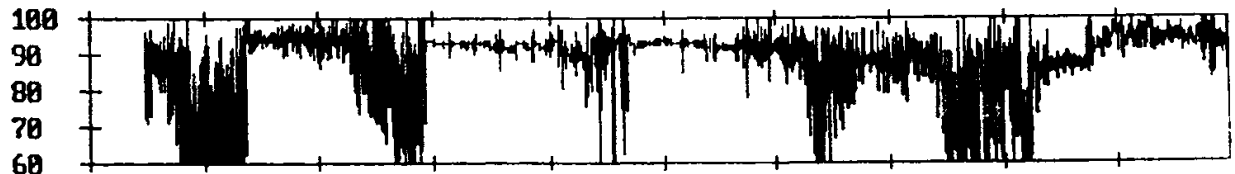

Heart Rate $b / m$ in

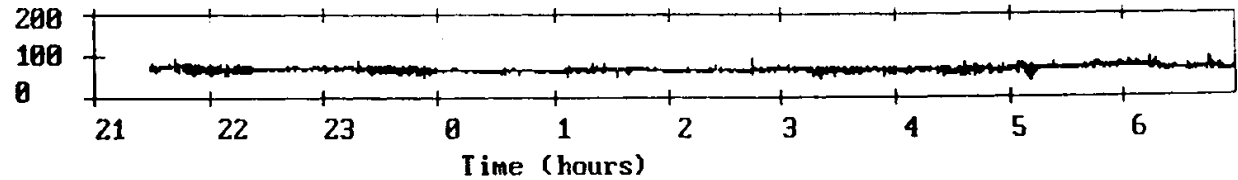

fig 1 - first PSG recording

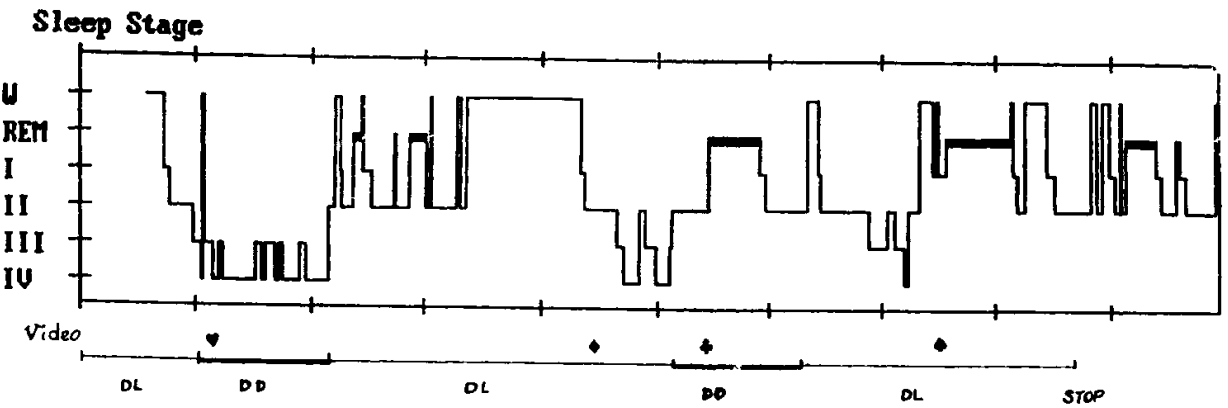

$\mathrm{SaO} 2 \%$

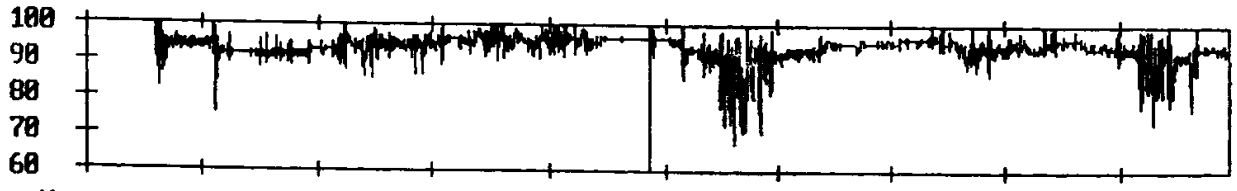

Heart Rate $b / m$ in

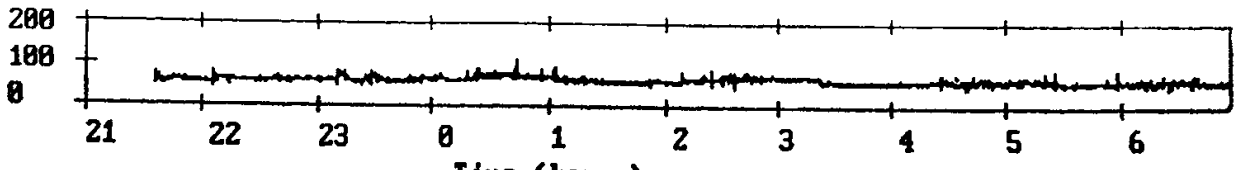

I ime (hours)

lg 2 - PSG associated to a video recording.

DL - lateral decubitus

DD = dorsal decubitus

$\checkmark$, $\bullet$ and $\bullet$ see video-photon. 
respiratory pattern suggested a possible effect of sleep posture. We therefore performed a second sleep study associated to a video recording (with a infrared camera) in which the patient was propped up by pillows to promote the lateral decubitus position. The results were spectacular. In NREM sleep, breathing was always regular with normal $\mathrm{SaO}$. In REM sleep, disordered breathing was only observed when the patient adopted the dorsal decubitus position (Fig. 2).

\section{CommonTs}

We conclude that in some thin patients with a positional form of SAHS, breathing during sleep can be regularized by simple and cost-effective measures of position control before embarking on more cumbersome and expensive procedures such as CPAP. For our patient this procedure was feasible because he had been institutionalized which allowed for close surveillance to be maintained during the night.

Acknowledgementa - The authors would like to thank the director of the Sleep Laboratory at St. Luc training Hospital, Prof. G. Aubert, for her helpful remarks.

\section{REFERENCLAS}

1. Cartwright RD. Effect of sleep position on sleep apnea severity. Sleep 1984, 7:110-114.

2. De Koninck $J$, Gagnon $P$, Lallier $S$. Sleep positions in the young adult and their relationship with the subjective quality of sleep. Sleep 1983, 6:52-59.

3. De Koninck J, Lorrain D, Gagnon P. Sleep positions and position shifts in five age groups: an ontogenetic picture. Sleep 1992, 15:143-149.

4. George CF, Millar TW, Kryger MH. Sleep apnea and body position during sleep. Sleep 1988, 11:90-99.

5. Lerner SA, Cecil WT. The effect of sleeping posture on obstructive sleep apnea. Chest $1984,86: 327$.

6. Pevernagie DA, Shepard WJr. Relations between sleep stage, posture and effective nasal CPAP levels in OSA. Sleep 1992, 15:162-167.

7. Vellody VP, Nassery M, Druz WS, Sharp JT. Effects of body position change on thoracoabdominal motion. J Appl Physiol Respirat Environ Exercise Physiol 1978, 45:581-589. 